\title{
The Applying of the VAK Method in Improving Learning Outcomes in Basketball Dribbling on Physical Education, Health and Recreation Students Faculty of Sport Science, State University of Medan
}

\author{
Muhammad Chairad ${ }^{1}$, Saipul Ambri Damanik ${ }^{2}$, Bangun Setia Hasibuan ${ }^{3}$ \\ $\left\{\right.$ chairad@unimed.ac.id ${ }^{1}$ \} \\ Department of Physical Education, Health And Recreation, Faculty Of Sport Science, \\ State University Of Medan, Indonesia ${ }^{1,2,3}$
}

\begin{abstract}
This study was aims to know increasing the results of learning basketball dribbling through the application of the V.A.K (visual, auditory, kinesthetic) method. It was conducted by using Classroom Action Research (CAR). It was conducted in two cycles. Subject of the study were the students of III semester B Class, it were 30 students of Physical Health and Recreation Education, Faculty Of Sport Science, State University Of Medan. The study was conducted on the basketball court of Faculty Of Sport Science, State University Of Medan in the 2018/2019. Techniques of collecting the data were by using observation sheets and test assessment portfolios. Based on the first test results of 30 students there were 12 students $(40 \%)$ who have reached the level of learning completeness with an average score of 74.07 student learning outcomes while there were 18 students who had not finished yet $(60 \%)$. The results of the first cycle have 21 students $(70 \%)$ who have reached the level of mastery learning with an average value of student learning outcomes 83.47 while there were 9 students $(30 \%)$ who did not complete it. In cycle II there were 27 students from 30 students $(90 \%)$ who have reached the level of learning completeness with an average score of 85.60 while there were 3 students $(10 \%)$ who did not complete it. Based on the data analysis we can concluded that the using use of the V.A.K (visual, auditory, kinesthetic) method can make a very large contribution and significant in improving the results of learning basketball dribbling on the student of Physical Education, Health and Recreation Department, Faculty Of Sport Science State University Of Medan of 2018/2019.
\end{abstract}

Keywords: Visual, Auditory, Kinesthetic method (V.A.K), Dribbling Basketball, Classroom Action Research (CAR).

\section{Introduction}

One of the most important things to improve the quality of education is the creation of learning effectiveness in carrying out every teaching and learning activity. The role of lecturers is expected to be able to create effectiveness in learning. One of the supporting factors in creating effective learning is using the right learning method. But based on the results of the first observations from basketball lecturers of Physical Education, Health and Recreation Department, Faculty Of Sport Science, State University Of Medan shows that in general the learning process in lectures only applies command styles and training methods, 
because basketball course is a course which practice in the field. Still lack of knowledge and the skills to apply various learning methods in the lecture resulted in low student interest and participation thus hampering the acquisition of skills and improving student learning outcomes.

To overcome these problems, efforts need to be made to improve, new changes or innovations in the teaching and learning process by implementing learning strategies that are more effective and efficient in improving student learning outcomes, especially the results of learning Dribbling in basketball games. There needs to be a renewal in learning to enable students to learn basketball dribbling material easier, faster, more meaningful, effective and fun, one of which is through visual auditory kinesthetic (V.A.K) methods.

Visual, Auditory, Kinesthetic (V.A.K) method is a learning method that can optimize all three learning modalities to make students feel comfortable. Through the V.A.K Method, students are taught to understand "how to learn" and "How to think", do activities based learning use the senses as much as possible. V.A.K Method which stands for the word Visual (learning by seeing, observing and describing something), Auditory (learning to talk and hear something), and kinesthetic (Learning through physical activity or moving and acting or direct involvement).

Rational reasons for using Kinesthetic Visual Auditory methods are that students will see hear and practice directly how the actual dribbling process is. Dribbling learning will be more interesting if actively involved in learning. However, the use of the VAK method is very rarely implemented in learning. This method is an alternative that can be chosen in learning, remembering in learning requires a form of activity which can direct students to be able to train and develop abilities through combining three styles namely visual style, auditory style and kinesthetic style. Thus the application of VAK learning methods to basketball dribbling material can improve student learning outcomes in basketball dribbling material.

\section{Research methodology}

This research was conducted by using Classroom Action Research (CAR). Where the study consists of four stages, there are planning, action, observation and reflection. It was conducted on the basketball court of Faculty Of Sport Science, State University Of Medan on August 2018. Subject of the research were the students of III semester B Class, it were 30 students of Physical Education, Health and Recreation, Faculty Of Sport Science, State University Of Medan. The following is a Class Action Research cycle.

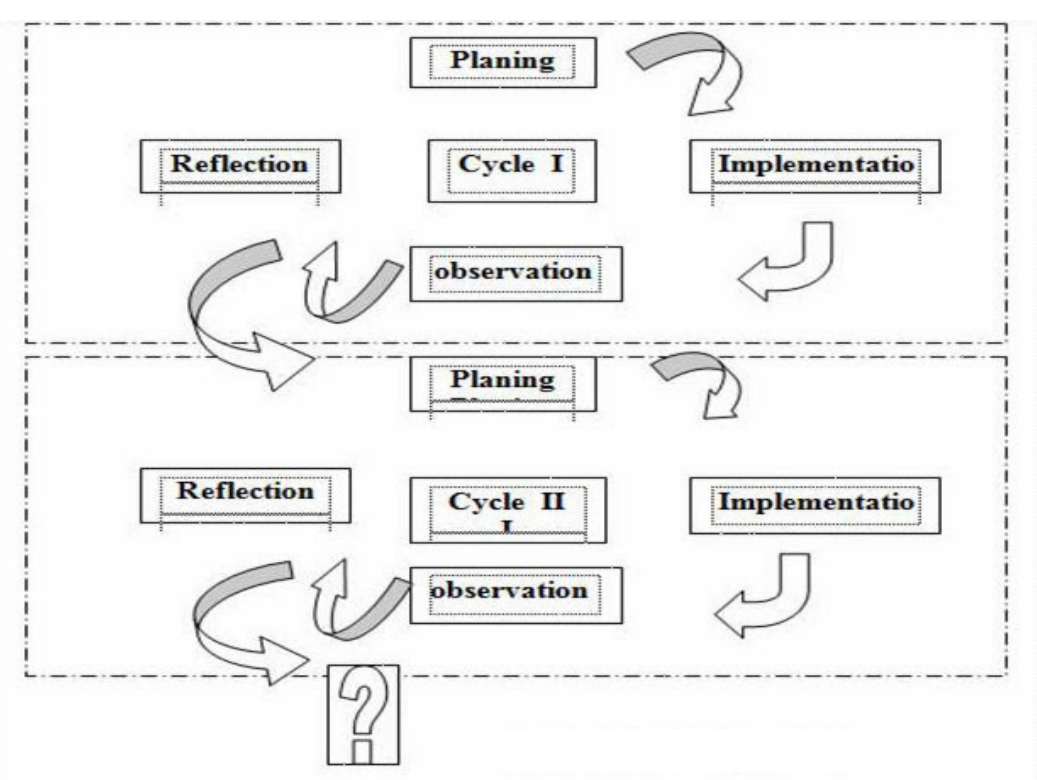


Figure 1. Classroom Action Research Cycle (CAR) (Source: Arikunto (2015:42))

The instrument used in this research was ability test to dribble with techniques / movements (Dribbling), lecturer observation sheet, and student observation sheet. Tools used: Basketball, Whistle, Basketball / Basket, Cone, research sheet and stationery.

\section{Research results and discussion}

Students are said to have completed their learning outcomes if the classical percentage reaches $85 \%$. When viewed, the initial test results are still far from the classical completeness threshold. This is shown from the results of the tests given to students at the beginning of the meeting. Because of that it was given an effort to improve student learning outcomes by giving action in cycle I and cycle II.

First cycle there were still many students who have not yet achieved the completeness of learning both individually and in completeness of classical learning. This is because there are difficulties experienced by students during the learning process. The successes and failures that occur in the implementation of the learning process in the first cycle action were students are very enthusiastic and eager in learning due to variations in learning so that every student in the group wants to be better than other groups, lecturers play an active role in giving motivation to students in the implementation of the basketball dribbling learning process, short time in cycle I so that in the mastery of basketball dribbling material, there are still many students who have not reached $K K M \geq 70$, the average student's difficulty in the attitude of implementation and continued movement, student learning outcomes in this cycle I have not yet achieved classical completeness, that is, only $70 \%$ of students who have fulfilled the KKM score while $30 \%$ of students have not yet completed.

Based on the results of the reflection of the first cycle, then it is used as a reference in providing action in cycle II to overcome student difficulties in basketball dribbling learning. To correct the weaknesses and increase the success of cycle I, it is necessary to do cycle II, namely lecturers are expected to motivate students to be more active in basketball dribbling learning, lecturers are expected to be able to maintain and enhance the learning activities that have been achieved previously, supervise students to focus on learning material, encouraging students to be more careful and increase repetition of the implementation attitude and the follow-up movement, encouraging students to increase information about basketball, especially dribbling techniques which consist of a beginning, continued implementation and movement attitudes.

Next is planning and taking action in cycle II. In cycle II, the researcher added time to do variations of learning so that in cycle II learning can increase. The following is presented in the table of efforts to overcome problems that occur in cycle II.

Table 1. The Efforts to Inerease Learning Outcomes in Cycle II

\begin{tabular}{lll}
\hline No. & Problem & Action \\
\hline & For asking questions, expressing opinions, & Tell students that if their friends ask \\
1 & $\begin{array}{l}\text { and answering questions during the learning } \\
\text { process, there are still many students who are }\end{array}$ & questions, express their opinions, or answer \\
afraid and shy to ask questions or answer & prize in the form of additional value.
\end{tabular}




\begin{tabular}{|c|c|c|}
\hline & $\begin{array}{l}\text { questions from lecturers. They feel } \\
\text { embarrassed if their answers are wrong, they } \\
\text { will be laughed at by their other friends. }\end{array}$ & \\
\hline 2 & $\begin{array}{l}\text { When doing basketball dribbling or start the } \\
\text { lesson, there are still students who play and } \\
\text { are not active in the lesson. }\end{array}$ & $\begin{array}{l}\text { Motivate students, which if they do not } \\
\text { concentrate on learning, students will not } \\
\text { understand the material they are studying, } \\
\text { and students will not know about basketball } \\
\text { dribbling lessons later. }\end{array}$ \\
\hline 3 & $\begin{array}{l}\text { When students do the basketball dribbling } \\
\text { movement, students make wrong moves. }\end{array}$ & $\begin{array}{l}\text { The lecturer immediately corrected the } \\
\text { wrong movement right away. }\end{array}$ \\
\hline
\end{tabular}

After carrying out the pre-planned actions, the result is an increase in all aspects, from the aspect of student activity and lecturers and student learning outcomes. From the learning outcomes obtained in cycle II, there was an increase from the first cycle and from the implementation of activities the students understood more and practice basic basketball dribbling techniques well through the application of learning variations. The results can be described as follows lecturers have been able to motivate students so that students can understand learning objectives, students want to ask lecturers and correct mistakes made, the activeness of students in participating in learning increases, knowledge and movement skills of students on the movement of the beginning attitude, the attitude of implementation, and the movement of basketball dribbling continued to improve both in each stage of the movement.

The increase in the implementation of this cycle II action can be described as follows students have looked more active and understand basketball dribbling movements, students seemed enthusiastic about basketball dribbling and enthusiasm in the learning process.

Overall, students have started better than before and on average students already know the basketball dribbling movement.

Table 2. Average value, beginning value, Cycle I, and Cycle II

\begin{tabular}{lllll}
\hline No. & Result test & Persentage & Average Value & Explanation \\
\hline 1. & First Data & $\begin{array}{l}\text { Completed } 40 \% \\
\text { Not Complete } 60 \%\end{array}$ & 62.50 & Not completed \\
2. & Cycle I & $\begin{array}{l}\text { Completed } 70 \% \\
\text { Not Complete } 30 \%\end{array}$ & 74.81 & Not completed \\
3. & Cycle II & $\begin{array}{l}\text { Completed } 90 \% \\
\text { Not Completed } 10 \%\end{array}$ & 82.31 & Completed \\
\hline
\end{tabular}

Based on the results of the study in the form of first data, cycle I and cycle II in the V.A.K method with a variety of basketball dribbling learning, it turned out that there had been a significant increase in learning outcomes. The average student score in the initial data was 62.50 , in cycle I it increased to 74.81 , and in cycle II it has reached 82.31 . With a percentage of initial data completeness of $40 \%$ (Not Completed), in the first cycle to $70 \%$ (Not Completed), and in cycle II it has reached 10\% (Completed)

From the results of research conducted, seen that the classical completeness in the first cycle was $30 \%$ then increased to $90 \%$ in cycle II. From data analysis can also be known that student learning outcomes from the learning outcomes test before using the V.A.K method with low learning variation. Then the V.A.K method was used with variations in learning in 
the learning process. It can be seen that student learning outcomes from the learning cycle test results using the V.A.K method with low learning variations; it was because students do not understand the truth of the movement of basketball and there were still some students while doing the movement process was not yet appropriate.

The obstacles faced by students in the teaching and learning process was still a lack of lecturers using learning methods and variations so that students are not interested in participating in lectures on dribbling material and make students become less active in learning processes. This is the basis for the low value of students in basketball dribbling material.

In dribbling material the lecture should be able to use the method or make learning variations. In order for students to be active in the learning process and will have a turn to make a move. Because in motion science, the more often you make a movement or the more you practice, will increasingly understand the process of the movement. Likewise with the movement of basketball dribbling, the more often students do it, the more understanding the movement will be.

\section{Conclusion}

Based on the results of the study, it can be concluded that "the applying of the V.A.K (Visual Auditory Kinesthetic) method through variations on dribbling learning going forward, dribbling while running, zig zag dribbling. In Improving Learning Outcomes Dribbling In Basketball Games of the students of Physical Education, Health and Recreation Faculty of Sport Science, State University of Medan 2018/2019." Based on the result of the research, it is suggested to the lecturers to consider the use of teaching style of inclusion and variation of learning to improve the results of learning dribbling in basketball games with customized material because its can inspire students to learn, It is recommended to the teacher / lecturer to motivate students to be more enthusiastic in learning, give special attention to the learning process for students that have not been completed and to the readers who might conduct research by using V.A.K (Visual Auditory Kinesthetic) method through learning variations it can be tried. 


\section{References}

[1] Arikunto, dkk.: Penelitian Tindakan Kelas. Bumi Aksara, Jakarta (2010)

[2] Dimyati.: Belajar dan Pembelajaran. Rineka Cipta, Jakarta (2006)

[3] FIBA.: Peraturan-peraturan Bola Basket, Official Basketball Rules. Pengurus Besar Persatuan Bola Basket Seluruh Indonesia (2008)

[4] Kristiyanto, A.: Penelitian Tindakan Kelas (PTK) dalam Pendidikan Jasmani dan Kepelatihan Olahraga. Semarang. UNS Press, (2010)

[5] PERBASI.: Peraturan Permainan dan Pertandingan Bola Basket, Jakarta (2006)

[6] Sukintaka.: Teori Pendidikan Jasmani. Nuansa, Bandung: (2004)

[7] Ahmadi, N.: Permainan Bola Basket. Era Intermedia (2007)

[8] Arikunto, Suharsimi dkk.: Penelitian Tindakan Kelas. Bumi Aksara, Jakarta (2006)

[9] Budiningsih, Asri.: Belajar dan Pembelajaran. PT Asdi Mahasatya, Jakarta (2012)

[10] Husdarta,Yudha.: Belajar Dan Pembelajaran. Bagian Proyek Penataran Guru SLTP setara D-III (2000)

[11] Ika Kusuma.: Stasstegi Belajar Mengajar Pendidikan jasmani. Fakultas Ilmu Keolahragaan UNIMED (2014)

[12] Mukholid, Agus.: Pendidikan Jasmani, Olahraga dan Kesehatan. Penerbit Yudhistira, Surakarta (2007)

[13] Oliver, J.: Dasar-dasar Bola Basket. PT Intan Sejati (2007)

[14] Rahayu, Trisna.: Strategi Pembelajaran Pendidikan Jasmani. Alfabe Bandung, Bandung (2014)

[15] Simaremare, Aman.: Kemampuan Dasar Mengajar. Universitas Negeri Medan, Fakultas Ilmu Pendidikan (2007)

[16] Slameto.: Belajar dan Faktor-Faktor Yang Mempengaruhinya. Rineka Cipta, Jakarta (2010)

[17] Subroto, Toto.: Pemantapan Kemampuan Mengajar. Bagian Proyek Penataran Guru SLTP setara D-III (2000)

[18] Sudjana, N.: Penilaian Hasil Proses Belajar Mengajar. PT Remaja Rosdakarya Offset-Bandung (2009)

[19] Sukintaka.: Teori Pendidikan Jasmani. Yayasan Nuansa Cendekia (2004)

[20] Sunarno, Syaiful.: Metode Penelitian Keolahragaan. Yuma Pustaka (2011)

[21] Sutrisno, Muhajir.: Buku Guru Pendidikan Jasmani, Olahraga, dan Kesehatan. Pusat Kurikulum Dan Perbukuan, Balitbang, Kemdikbud (2014) 